\title{
Effects of bovine colostrum acid protein on bone loss and hemobiochemistry indexes in rats
}

\author{
Ming $\mathrm{Du}^{1}$, Kejian $\mathrm{WANG}^{2}$, Chengtie $\mathrm{Wu}^{3}$, Lanwei ZHANG ${ }^{1 *}$ \\ ${ }^{1}$ College of Food Science and Engineering, Harbin Institute of Technology, Harbin 150090, China \\ ${ }^{2}$ Institute of Forestry and Pomology, Beijing Academy of Agriculture and Forestry Sciences, \\ Beijing 100093, China \\ ${ }^{3}$ Biomaterials and Tissue Engineering Research Unit, The University of Sydney, \\ New South Wales 2006, Australia
}

\author{
Received 16 October 2008 - Revised 24 February 2009 - Accepted 16 April 2009 \\ Published online 23 June 2009
}

\begin{abstract}
At present, researchers all over the world focus on the methods to prevent and cure osteoporosis. Many reports have shown that bovine milk and its basic proteins, and bovine colostrums (BC) and their extracts have positive effects on bone growth of human beings or experimental rats, such as increasing bone mineral density (BMD) and promoting calcium absorption. However, to our best knowledge, the effects of acid proteins from BC (BCAP) on bone properties have not been reported, and the effect on the potential hazard on blood lipids of rats has not been reported. This study investigated the effect of BCAP on bone loss in aged ovariectomized (OVX) rats and the hemobiochemistry parameters (HP) in serum. Forty-eight female SpragueDawley rats of clean grade were ovariectomized and another 12 rats received a sham operation. The OVX rats were randomly separated into four groups, i.e. OVX control, OVX low dose $\left(0.04 \mathrm{~g} \cdot \mathrm{d}^{-1}\right)$, OVX medium dose $\left(0.20 \mathrm{~g} \cdot \mathrm{d}^{-1}\right)$, and OVX high dose $\left(0.40 \mathrm{~g} \cdot \mathrm{d}^{-1}\right)$. BCAP were applied in rat diet for 12 weeks and the rats were gavaged once a day. The effects of BCAP on HP, calcium content (CC), and BMD of femur were determined using biochemical analysis, atomic absorption spectrophotometry, and dual-energy X-ray absorptiometry. Results showed that BCAP could increase the femur weight/length. CC of femurs in rats with BCAP were significantly higher than those of shamoperated group and model control group. BCAP increased the BMD of femur. However, BCAP at a low dosage exhibited higher activity than that at a medium or high dosage. BCAP had no particular effects on the HP of rats. It is concluded that BCAP at dose $<0.04 \mathrm{~g} \cdot \mathrm{d}^{-1}$ can prevent osteoporosis caused by bone loss due to estrogen reduction in OVX rats, and BCAP $\left(0.04-0.40 \mathrm{~g} \cdot \mathrm{d}^{-1}\right)$ has no potential hazard on blood lipids of rats under present experimental condition.
\end{abstract}

bovine colostrum / acid protein / bone property / hemobiochemistry / ovariectomized rat

摘要 - 牛初乳酸性蛋白对大鼠骨质流失及血清生化指标影响研究。目前, 许多研究者正致 力于预防和治疗骨质疏松的研究。研究表明, 牛乳、牛乳碱性蛋白、牛初乳及牛初乳提取 物均可以促进人或实验动物的骨骼生长, 如增加骨密度和促进钻吸收等。然而, 牛初乳酸 性蛋白组分 (BCAP) 对于骨骼生长的影响还未见报导, 对血脂水平的影响也未见报导。本 文研究了 BCAP 对去势大鼠骨质流失及血清生化指标的影响。60 只 SD 大鼠随机分为 5 组, 其中 48 只大鼠进行了卵巢切除手术 $(\mathrm{OVX})$, 另外 12 只大鼠进行了假手术。卵巢切除 大鼠随机分为四组, 分别为 OVX-对照组、OVX-低剂量组 $\left(0.04 \mathrm{~g} \cdot \mathrm{d}^{-1}\right) 、 O V X-$-中剂量组 $\left(0.20 \mathrm{~g} \cdot \mathrm{d}^{-1}\right)$ 和 OVX-高剂量组 $\left(0.40 \mathrm{~g} \cdot \mathrm{d}^{-1}\right)$, 喂食 BCAP 的各组大鼠连续灌胃 12 周, 每天

*Corresponding author (通讯作者): duming2006@yahoo.com.cn 


\begin{abstract}
灌胃一次。分别采用生化分析方法、原子吸收光谱法和双能 X-射线法测定了大鼠的血清生 化指标、骨钻含量和骨密度等。结果表明: 喂食 BCAP 各组大鼠的 [股骨重/股骨长]较模型 对照组显著增加, 骨钻含量和骨密度显著高于假手术组和模型对照组; 低剂量组效果明显优 于中剂量组和高剂量组。而且, 各组大鼠的血清生化指标未见显著差异。因此得出结论: 在 低剂量 $\left(\leq 0.04 \mathrm{~g} \cdot \mathrm{d}^{-1}\right)$ 条件下, BCAP 具有预防去势大鼠因雌激素下降造成的骨质流失的功 效；在本实验条件下，喂食 BCAP $\left(0.04 \sim 0.40 \mathrm{~g} \cdot \mathrm{d}^{-1}\right)$ 不会造成大鼠的血脂升高。
\end{abstract}

\title{
牛初乳 / 酸性蛋白 / 骨骼特性 / 血清生化指标 / 卵巢切除大鼠
}

Résumé - Effets de la protéine acide du colostrum bovin sur la perte osseuse et les indices hémobiochimiques chez le rat. La recherche de méthodes de prévention et de traitement de l'ostéoporose fait actuellement l'objet d'études partout dans le monde. De nombreuses publications ont montré que le lait de vache et ses protéines basiques, le colostrum bovin et ses extraits, ont un effet positif sur la croissance osseuse de l'Homme ou des rats, en accroissant la densité minérale osseuse et en favorisant l'absorption du calcium. Cependant, à notre connaissance, les effets des protéines acides du colostrum bovin (PACB) sur les propriétés des os n'ont jamais été rapportés, pas plus que l'effet sur le risque potentiel sur les lipides du sang chez le rat. Cette étude a porté sur l'effet des PACB sur la perte osseuse chez des rattes âgées ovariectomisées (OVX) et sur les paramètres hémobiochimiques du sérum. Des rattes Sprague-Dawley en bon état ont été soit ovariectomisées (48), soit opérées fictivement (12). Les rattes OVX ont été séparées aléatoirement en 4 groupes : OVX contrôle, OVX faible dose $\left(0,04 \mathrm{~g} \cdot \mathrm{j}^{-1}\right)$, OVX dose moyenne $\left(0,20 \mathrm{~g} \cdot \mathrm{j}^{-1}\right)$ et OVX dose élevée $\left(0,40 \mathrm{~g} \cdot \mathrm{j}^{-1}\right)$. Les PACB ont été introduites dans leur régime alimentaire pendant 12 semaines sous forme de gavage une fois par jour. Les effets des PACB sur les paramètres hémobiochimiques, teneur en calcium et densité minérale osseuse du fémur ont été déterminés par analyse biochimique, spectrophotométrie d'absorption atomique et absorptiométrie biénergique à rayons $\mathrm{X}$. Les résultats ont montré que les $\mathrm{PACB}$ pouvaient augmenter le rapport poids/longueur du fémur. Les teneurs en calcium des fémurs de rattes avec PACB étaient significativement plus élevées que celles du groupe opéré fictivement et du groupe de contrôle. Les PACB augmentaient la densité minérale osseuse du fémur. Cependant, les PACB à faible dose avaient une activité supérieure à celle des doses moyennes et élevées. Les PACB n'avaient pas d'effet particulier sur les paramètres hémobiochimiques des rattes. On en conclut que les PACB à doses inférieures à $0,04 \mathrm{~g} \cdot \mathrm{j}^{-1}$ peuvent prévenir l'ostéoporose provoquée par la perte osseuse due à la réduction des œstrogènes chez les rattes ovariectomisées, et que des doses de PACB de 0,04 à $0,40 \mathrm{~g} \cdot \mathrm{j}^{-1}$ ne présentent pas de risque pour les lipides du sang des rattes dans ces conditions expérimentales.

colostrum bovin / protéine acide / propriété osseuse / hémobiochimie / ratte ovariectomisée

\section{INTRODUCTION}

Osteoporosis is presently one of the most critical global health disorders associated with advancing age, especially among postmenopausal women. Menopause results in elevated bone turnover, an imbalance between bone formation and bone resorption, and decreased bone mineral density (BMD). Osteoporosis is mainly caused by the decline of BMD both in human beings and in experimental animals $[14,16,34$, 37]. Bioactive factors from milk may affect bone metabolism directly as milk has a functional role in the growth of newborn animals. In this respect, any factor leading to a reduction in the rapid menopausal bone loss can impose the perceived risk of osteoporosis in older women. Osteoprotegerin is a member of the tumor necrosis factor superfamily and inhibits osteoclast activity and regulates the immune system. Previous studies have indicated that osteoprotegerin may contribute to the antiresorptive activity of bovine colostrums (BC) and milk on bone [43]. Milk basic protein (MBP) is 
a group of bioactive proteins from bovine whey $[27,39,40]$. Some research results suggest that MBP suppresses the osteoclast-mediated bone resorption, increases the BMD, and prevents bone loss caused by ovariectomy (OVX) [26, 30, 40]. MBP dose-dependently suppressed the number of pits formed by these osteoclasts, and thus suppressed bone resorption [26, 27, 40, 45]. Moreover, MBP has been evaluated for its use as an ingredient in food and concluded to be safe for its intended use [20].

A comparison between acidic and basic protein fractions from whey or milk for reduction of bone loss in OVX rats was carried out by Kruger et al. [22]. It was reported that whey acidic protein fractions (WAF) protected against bone loss due to OVX in the mature female rats. Their results of BMD of the spine and femur indicated that the acidic protein fractions reduced bone loss due to OVX and maintained bone density above OVX levels. According to the biomechanical data analysis, they also reported that the acid proteins from milk and whey had similar positive effects on bone stiffness, and hence resistance against breaking [22].

Influences of bovine colostrums extract (BCE) on osteoblast proliferation and bone growth of fetal rats have been determined by Yao et al. [47]. Their results showed that the promotion activity of $\mathrm{BCE}$ on bone development was more remarkable than that of calcium. Compared with regular bovine milk, BC not only contain abundant protein but also enrich bioactive components that can produce many physiological functions, such as immune regulation activity, antimicrobial activity, muscular/skeletal repair, and bone growth and development enhancement [7, 17, 19, 23]. Studies have shown that colostrums are the only natural source of two major growth factors, namely (1) transforming growth factors alpha and beta and (2) insulin-like growth factors 1 and 2 (IGF-1 and IGF-2). These growth factors have significant characteristics for repairing muscle and cartilage [41].
The products made from colostrums have been marketed for their health benefits for many years and are generally regarded as safe. Although colostrums are known to contain a large number of biologically active molecules, the effect on hemobiochemistry parameters (HP) has not been investigated when colostrums were used for diet over extended periods of time.

Since BC has more advantages on biological characteristics than mature bovine milk, its bioactivity on bone growth and characteristics has been a major interest in research. There have been many studies on the health functions of proteins from BC. However, the direct or indirect effects of $\mathrm{BC}$ on the properties of bone have not been extensively investigated. The effect of acid proteins from BC (BCAP) on the blood biochemistry parameters of rats has not been reported, which was necessarily determined based on the higher concentration of colostrums' nutrients and components. The aim of this study was to investigate the effects of BCAP on the prevention of bone loss in aged OVX rats and HP of rats.

\section{MATERIALS AND METHODS}

\subsection{Preparation of BCAP}

BCAP for this study was obtained from fresh $\mathrm{BC}$ (the milk produced for the first $24 \mathrm{~h}$ in lactation), milking from local farms. After refrigerated rapidly, the milk was stored at $4{ }^{\circ} \mathrm{C}$ and processed within $12 \mathrm{~h}$. The colostrum was defatted by centrifugation $\left(15000 \times \mathrm{g}, 20 \mathrm{~min}, 4^{\circ} \mathrm{C}\right)$, sterilized by $0.22 \mu \mathrm{m}$ ceramic membrane filtration (GEA Filtration, Global Engineering Alliance, Bochum, Germany) $\left(30^{\circ} \mathrm{C}, 6\right.$ bar $)$, concentrated by ultrafiltration membrane with a molecular weight cut-off of $5000 \mathrm{~kg} \cdot \mathrm{mol}^{-1}$ $\left(15^{\circ} \mathrm{C}\right)$; some rennet was then added to the solution according to the enzyme's activity, and the precipitated casein was removed 
Table I. Dietary composition $\left(\mathrm{g} \cdot \mathrm{kg}^{-1}\right)$.

\begin{tabular}{|c|c|c|c|c|}
\hline Group & Control (A/B) & $\mathrm{C} 1$ & $\mathrm{C} 2$ & $\mathrm{C} 3$ \\
\hline Sodium caseinate & 150 & 148 & 140 & 130 \\
\hline BCAP & 0 & $0.04 \mathrm{~g} \cdot \mathrm{d}^{-1^{*}}$ & $0.20 \mathrm{~g} \cdot \mathrm{d}^{-1^{*}}$ & $0.40 \mathrm{~g} \cdot \mathrm{d}^{-1^{*}}$ \\
\hline Cystine & 2.7 & 2.7 & 2.7 & 2.7 \\
\hline Glycine & 3.3 & 3.3 & 3.3 & 3.3 \\
\hline Methionine & 1.5 & 1.5 & 1.5 & 1.5 \\
\hline Glutamine & 7 & 7 & 7 & 7 \\
\hline Cellulose & 50 & 50 & 50 & 50 \\
\hline$V_{i t a m i n} \operatorname{mix}^{* *}$ & 50 & 50 & 50 & 50 \\
\hline Mineral mix ${ }^{* *}$ & 50 & 50 & 50 & 50 \\
\hline Corn oil & 50 & 50 & 50 & 50 \\
\hline $\mathrm{CaCO}_{3}$ & 12.5 & 12.5 & 12.5 & 12.5 \\
\hline Starch & 623 & 623 & 623 & 623 \\
\hline Total & 1000 & 1000 & 1000 & 1000 \\
\hline
\end{tabular}

${ }^{*}$ So as to make the fair diet for each group, the gavaged dosage of BCAP and the content of sodium caseinate in groups $\mathrm{C} 1, \mathrm{C} 2$, and $\mathrm{C} 3$ was equal to the content of sodium caseinate in groups $\mathrm{A}$ and $\mathrm{B}$ almost. The mean food intake over the trial was $20 \mathrm{~g} \cdot \mathrm{d}^{-1}$ per animal.

${ }^{* * *}$ Formulated by Crop and Food Research, New Zealand, according to the National Research Council (1995) nutrient requirements for laboratory animals (AIN 93M). A, sham operation; B, OVX model control; C1, OVX rats gavaged with BCAP of $0.04 \mathrm{~g} \cdot \mathrm{d}^{-1}$; C2, OVX rats gavaged with BCAP of $0.20 \mathrm{~g} \cdot \mathrm{d}^{-1}$; and C3, OVX rats gavaged with BCAP of $0.40 \mathrm{~g} \cdot \mathrm{d}^{-1}$.

by centrifugation $\left(15000 \times \mathrm{g}, 20 \mathrm{~min}, 10^{\circ} \mathrm{C}\right)$. The sequential whey was concentrated by ultrafiltration membrane with a molecular weight cut-off of $1000 \mathrm{~kg} \cdot \mathrm{mol}^{-1}\left(15^{\circ} \mathrm{C}\right)$ and loaded onto a column that had been packed with anion exchange resin, $\mathrm{DEAE}_{52}$ cellulose (GE Healthcare, Uppsala, Sweden). The column was sufficiently washed with deionized water ( $\mathrm{pH} \mathrm{6.9)}$ and the bound protein was eluted with $1 \mathrm{~mol} \cdot \mathrm{L}^{-1} \mathrm{NaCl}$ solution ( $\mathrm{pH}$ 6.9), the $\mathrm{pH}$ was adjusted using hydrochloric acid $\left(0.1 \mathrm{~mol} \cdot \mathrm{L}^{-1}\right)$. BCAP was then obtained by lyophilization and stored at $-20{ }^{\circ} \mathrm{C}$, after dialysis of the eluted fraction in a cellulose membrane tube (Millipore, Billerica, Massachusetts, USA).

\subsection{Animals and diets}

Sixty female Sprague-Dawley rats (BW $195 \pm 15 \mathrm{~g}$ ) were supplied by the Experimental Animals Center of Harbin Medical University in China. Guidelines for the Care and Use of Animals were followed and approved by the Ethical Committee of Harbin Medical University. Forty-eight of the rats were OVX and the other 12 received a sham operation (A). The animals were fed a modified AIN-76 diet $[1,2]$ (control diet in Tab. I) for a 3-week recovery period after the operation. Afterward, the OVX rats were randomly separated into four groups, i.e. OVX-control group (B), OVX-0.04 $\mathrm{g} \cdot \mathrm{d}^{-1}$ BCAP (C1), OVX-0.20 $\mathrm{g} \cdot \mathrm{d}^{-1}$ BCAP (C2), and OVX-0.40 $\mathrm{g} \cdot \mathrm{d}^{-1}$ BCAP (C3). The dose of the fraction was selected according to published studies on the MBP [40] and WAF [21]. Animals had access ad libitum to deionized water. Animals in different groups were fed a casein-based semi-synthetic diet for 12 weeks, as given in Table I. The sham and the OVX-control groups received the base diet, and the rats in groups $\mathrm{C} 1, \mathrm{C} 2$, and $\mathrm{C} 3$ were gavaged with $\mathrm{BCAP}$ according to the modified diet composition once a day. The daily intake of the animals was measured, and their intake was adjusted weekly according to the sham group's body weight 
in order to prevent excessive body weight gain in the OVX groups. The experimental method was guided by a previous report [26]. Ten rats in each group were used for data measurement. The experiment was performed according to the Guidelines for the Care and Use of Animals and was approved by the Ethical Committee of Harbin Medical University, according to national legislation.

\subsection{Assay of blood biochemistry parameters in $\mathrm{OVX}$ rats}

At the end of experiment, the serums from killed rats in all groups were separated. Seven kinds of hemobiochemistry indexes in serum of each group, such as total protein (TP), total cholesterol (TCH), glucose (GLU), high density lipoprotein-cholesterol (HDL-C), low density lipoprotein-cholesterol (LDL-C), triglyceride (TG), and albumin (Alb), were determined using Auto Biochemical Analysis Instrument (Hitachi 7170A, Tokyo, Honshu, Japan). The experimental method was guided by a previous report [26].

\subsection{Length and weight of femur investigation}

The bone wet weight was obtained using an analytical balance (FA1004N, MoreChina, Shanghai, China), and the bone length by a vernier caliper (Mitutoyo China, Tianjin, China).

\subsection{BMD and calcium content determination}

The left femur was divided into three aliquots (proximal end, middle segment, and distal end) with a bone saw (Yongkang Tiange Electric Ltd., Guangzhou, China) in order to examine the difference in the effect on the various segments. BMD of the three aliquots of femur was measured with dual-energy X-ray absorptiometry, using a Dichroma Scan DCS-600A (Aloka, Tokyo, Japan) with beam energies of 22 and $53 \mathrm{keV}$ adapted for measuring small animals. The scanning speed was $10 \mathrm{~mm} \cdot \mathrm{s}^{-1}$. The stability of the measurement was controlled by scanning a phantom for calibration, each time the machine was turned on.

After each weight was measured, all right femurs were dried at $105^{\circ} \mathrm{C}$ in an oven. The calcium content (CC) of each femur was then determined using atomic absorption spectrophotometry (PerkinElmer AAnalyst 100, Waltham, Massachusetts, USA) employing a hollow cathode lamp at $422.7 \mathrm{~nm}$ and a slit width of $0.7 \mathrm{~nm}$, after wet digestion $\left(\mathrm{HNO}_{3}: \mathrm{HClO}_{4}, 4: 1 ; \mathrm{v} / \mathrm{v}\right)$ and addition of $2 \%(\mathrm{w} / \mathrm{v})$ lanthanum as $\mathrm{La}_{2} \mathrm{O}_{3}$. The working standard solutions were prepared with $\mathrm{CaCl}_{2}$.

\subsection{Identifications of proteins in BCAP}

The lyophilized BCAP was dissolved in $0.2 \mathrm{~mol} \cdot \mathrm{L}^{-1}$ phosphate-buffered solution (PBS) ( $\mathrm{pH}$ 6.9). Fractions of BCAP were isolated consecutively by Sephadex G-100 column $(1.5 \times 35 \mathrm{~cm}) \quad(\mathrm{GE}$ Healthcare, Uppsala, Sweden) and Econo-pac Q prepacked column $(0.59 \times 3.6 \mathrm{~cm})($ Bio-RAD Co., Beijing, P. R. China). Size exclusion chromatography was run with a buffer mobile phase $\left(0.2 \mathrm{~mol} \cdot \mathrm{L}^{-1} \mathrm{PBS}, \mathrm{pH} 6.9\right)$ at a flow rate of $0.5 \mathrm{~mL} \cdot \mathrm{min}^{-1}$. According to the purity requirement, the fraction from Sephadex G-100 was purified further by Econo-pac Q. Anion exchange chromatography was performed using $1.0 \mathrm{~mol} \cdot \mathrm{L}^{-1}$ $\mathrm{NaCl} 0.2 \mathrm{~mol} \cdot \mathrm{L}^{-1} \mathrm{PBS}(\mathrm{pH}$ 6.9) buffer as a mobile phase with a $0.1-1.0 \mathrm{~mol} \cdot \mathrm{L}^{-1}$ $\mathrm{NaCl}$ linear salt gradient at a flow rate of $0.8 \mathrm{~mL} \cdot \mathrm{min}^{-1}$. The whole chromatography was performed at $4{ }^{\circ} \mathrm{C}$ with column effluent monitored at $280 \mathrm{~nm}$. The eluted fraction was concentrated by ultrafiltration after which it was dialyzed exhaustively against ultra-pure water. Each purified protein fraction was identified by $\mathrm{N}$-terminal amino 
acid sequence analysis technique at the National Center of Biomedical Analysis of China.

\subsection{Statistical analysis}

A total of 60 rats (12 per group) were used in the trial and 10 rats selected randomly from each group were used for statistical analysis. Differences among the groups were determined by one-way analysis of variance. All statistical calculations were performed using the SPSS (Statistical Product and Service Solutions) 11.0 package software (SPSS Inc., Chicago, Illinois, USA). Significance was assigned at $P<0.05$. Values and graphs are expressed and shown as mean values with standard deviation (SD).

\section{RESULTS}

\subsection{Assay of HP in normal and $\mathrm{OVX}$ rats}

TP, TCH, GLU, HDL-C, LDL-C, TG, and $\mathrm{Alb}$ in serum were determined using Auto Biochemical Analysis Instrument. As shown in Table II, TCH in group B was significantly higher than that in groups $\mathrm{A}, \mathrm{C} 1$, $\mathrm{C} 2$, and $\mathrm{C} 3(P<0.05)$. GLU in groups $\mathrm{B}$ and $\mathrm{C} 1$ was higher than that in group $\mathrm{A}$ $(P<0.05)$. GLU in groups $\mathrm{C} 2$ and $\mathrm{C} 3$ were not significantly different from that in groups $\mathrm{A}, \mathrm{B}$, and $\mathrm{C} 1(P>0.05)$. TG in groups $\mathrm{C} 1$ and $\mathrm{C} 3$ was not significantly different from that in groups $\mathrm{A}, \mathrm{B}$, and $\mathrm{C} 2$, although $\mathrm{TG}$ in group $\mathrm{C} 2$ was lower than that in group $\mathrm{B}(P<0.05)$. As for HDL-C, LDL-C, TP, and Alb, each HP in all groups has no distinct difference, respectively $(P>0.05)$.

In the mass, BCAP has no positive or passive effects on blood biochemistry parameters of rats, which indicated that BCAP can be added to food as a functional additive without negative activity on serum of normal and OVX rats.

\subsection{Effect of BCAP on femur weight of rats}

The values of weight/length $(W / L)$ of group B, left and right femurs, were significantly lower than those of group A $(P<0.05)$ (Tab. III). The values of $W / L$ (both left and right) in groups $\mathrm{C} 1, \mathrm{C} 2$, and C3 were all higher than those of groups $\mathrm{A}$ and B. Meanwhile, the values among groups $\mathrm{C} 1, \mathrm{C} 2$, and $\mathrm{C} 3$ had no obvious difference $(P>0.05)$, which indicated that BCAP has positive effect on femur of rats. Therefore, it is possible that BCAP has a positive effect on the growth of femur in rats, but not in a dose-dependent manner.

There are many well-known factors affecting $W / L$, such as the average area of cross-section, the $\mathrm{CC}$ of marrow, and the density of marrow. Hence, $W / L$ is not an effective index of BMD, even though it can be an indirect reflection of BMD. The lower values of $W / L$ of group B compared with those of group A could be caused by a lower BMD and (or) a higher length. Based on the above results, $W / L$ cannot reflect the change in bone density of rats directly. It may be used as an indirect indicator of the BCAP effect on bone growth. Therefore, BMD determination becomes necessary to reflect the situation of bone loss in OVX rats.

\subsection{Effect of BCAP on CC of femur of rats}

Figure 1 shows that the $\mathrm{CC}$ in femur of rats in group $\mathrm{B}$ was lower than that of group A $(P<0.05)$, indicating a successful ovariectomizing operation. CC of groups $\mathrm{C} 1$, $\mathrm{C} 2$, and $\mathrm{C} 3$ was higher than those of groups $\mathrm{B}$ and $\mathrm{A}(P<0.05)$. This suggests that BCAP had an affirmative effect on the calcium metabolism of femur in rats, which can alleviate or suppress the $\mathrm{CC}$ 
Table II. Results (mean $\pm \mathrm{SD}, n=10$ ) of hemobiochemical index determination.

\begin{tabular}{lccccc}
\hline Indexes & A & B & C1 & C2 & C3 \\
\hline TCH $\left(\mathrm{mmol} \cdot \mathrm{L}^{-1}\right)$ & $2.1286 \pm 0.1309^{\mathrm{a}}$ & $2.5339 \pm 0.2286^{\mathrm{b}}$ & $2.1558 \pm 0.1653^{\mathrm{a}}$ & $2.3940 \pm 0.2287^{\mathrm{a}}$ & $2.3760 \pm 0.2722^{\mathrm{a}}$ \\
GLU $\left(\mathrm{mmol} \cdot \mathrm{L}^{-1}\right)$ & $5.65 \pm 0.65^{\mathrm{b}}$ & $4.78 \pm 0.50^{\mathrm{a}}$ & $4.68 \pm 0.49^{\mathrm{a}}$ & $4.96 \pm 0.45^{\mathrm{ab}}$ & $5.44 \pm 0.55^{\mathrm{ab}}$ \\
TG $\left(\mathrm{mmol} \cdot \mathrm{L}^{-1}\right)$ & $0.4202 \pm 0.0371^{\mathrm{a}}$ & $0.5420 \pm 0.0497^{\mathrm{b}}$ & $0.5043 \pm 0.0385^{\mathrm{ab}}$ & $0.4619 \pm 0.0367^{\mathrm{a}}$ & $0.4924 \pm 0.0252^{\mathrm{ab}}$ \\
HDL-C $\left(\mathrm{mmol} \cdot \mathrm{L}^{-1}\right)$ & $1.1938 \pm 0.1091^{\mathrm{a}}$ & $1.2572 \pm 0.0997^{\mathrm{a}}$ & $1.1783 \pm 0.1125^{\mathrm{a}}$ & $1.1813 \pm 0.1043^{\mathrm{a}}$ & $1.2474 \pm 0.1207^{\mathrm{a}}$ \\
LDL-C $\left(\mathrm{mmol} \cdot \mathrm{L}^{-1}\right)$ & $0.5873 \pm 0.0935^{\mathrm{a}}$ & $0.5321 \pm 0.0898^{\mathrm{a}}$ & $0.5908 \pm 0.072 \mathrm{a}^{\mathrm{a}}$ & $0.5987 \pm 0.0949^{\mathrm{a}}$ & $0.5791 \pm 0.0744^{\mathrm{a}}$ \\
TP $\left(\mathrm{g} \cdot \mathrm{L}^{-1}\right)$ & $63.29 \pm 5.05^{\mathrm{a}}$ & $64.36 \pm 4.39^{\mathrm{a}}$ & $63.71 \pm 5.06^{\mathrm{a}}$ & $65.59 \pm 4.89^{\mathrm{a}}$ & $63.90 \pm 3.17^{\mathrm{a}}$ \\
Alb $\left(\mathrm{g} \cdot \mathrm{L}^{-1}\right)$ & $30.96 \pm 2.86^{\mathrm{a}}$ & $31.36 \pm 2.61^{\mathrm{a}}$ & $32.44 \pm 2.26^{\mathrm{a}}$ & $30.68 \pm 2.66^{\mathrm{a}}$ & $31.78 \pm 2.48^{\mathrm{a}}$ \\
\hline
\end{tabular}

Note: A, sham operation; B, OVX model control; C1, OVX rats gavaged with BCAP of $0.04 \mathrm{~g} \cdot \mathrm{d}^{-1}$; C2, OVX rats gavaged with BCAP of $0.20 \mathrm{~g} \cdot \mathrm{d}^{-1}$; C3, OVX rats gavaged with BCAP of $0.40 \mathrm{~g} \cdot \mathrm{d}^{-1}$. Values followed by different single letters in the same column are significantly different $(P<0.05)$.

a, b Values are not significantly different with value followed by letter a or $\mathrm{b}$ in the same row $(P>0.05)$. 
Table III. Results (mean $\pm \mathrm{SD}, n=10$ ) of femur $W / L$.

\begin{tabular}{lcc}
\hline Group & Left femur $W / L\left(\mathrm{~g} \cdot \mathrm{cm}^{-1}\right)$ & Right femur $W / L\left(\mathrm{~g} \cdot \mathrm{cm}^{-1}\right)$ \\
\hline A & $0.2252 \pm 0.0113^{\mathrm{b}}$ & $0.2243 \pm 0.0103^{\mathrm{b}}$ \\
B & $0.2173 \pm 0.0101^{\mathrm{a}}$ & $0.2156 \pm 0.0100^{\mathrm{a}}$ \\
C1 & $0.2357 \pm 0.0152^{\mathrm{c}}$ & $0.2347 \pm 0.0127^{\mathrm{c}}$ \\
C2 & $0.2309 \pm 0.0128^{\mathrm{c}}$ & $0.2306 \pm 0.0175^{\mathrm{c}}$ \\
C3 & $0.2312 \pm 0.0071^{\mathrm{c}}$ & $0.2302 \pm 0.0093^{\mathrm{c}}$ \\
\hline
\end{tabular}

Note: A, sham operation; B, OVX model control; C1, OVX rats gavaged with BCAP of $0.04 \mathrm{~g} \cdot \mathrm{d}^{-1} ; \mathrm{C} 2$, OVX rats gavaged with BCAP of $0.20 \mathrm{~g} \cdot \mathrm{d}^{-1}$; C3, OVX rats gavaged with BCAP of $0.40 \mathrm{~g} \cdot \mathrm{d}^{-1}$. Values followed by different letters in the same column are significantly different $(P<0.05)$.

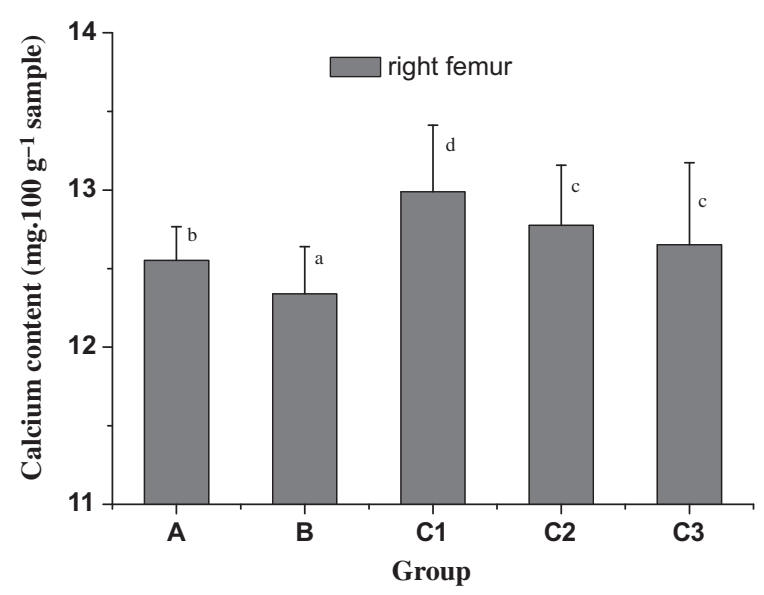

Figure 1. $\mathrm{CC}$ of femur (mean $\pm \mathrm{SD}, n=10$ ). The $\mathrm{CC}$ of each right femur was determined using atomic absorption spectrophotometry method. A, sham operation; B, OVX model control; $\mathrm{C} 1$, OVX rats diet with BCAP of $0.04 \mathrm{~g} \cdot \mathrm{d}^{-1} ; \mathrm{C} 2$, OVX rats diet with BCAP of $0.20 \mathrm{~g} \cdot \mathrm{d}^{-1} ; \mathrm{C} 3$, OVX rats diet with BCAP of $0.40 \mathrm{~g} \cdot \mathrm{d}^{-1}$. Values followed by different letters are significantly different $(P<0.05)$.

declining that had resulted from the OVX; i.e. BCAP had curative effects on osteoporosis in aged rats. However, it was interestingly observed that $\mathrm{CC}$ of the group diet with low dose $\left(\mathrm{C} 1, \quad 0.04 \mathrm{~g} \cdot \mathrm{d}^{-1}\right)$ was significantly different $(P<0.05)$ from the groups $\mathrm{C} 2 \quad\left(0.20 \mathrm{~g} \cdot \mathrm{d}^{-1}\right)$ and $\mathrm{C} 3$ $\left(0.40 \mathrm{~g} \cdot \mathrm{d}^{-1}\right)$, but $\mathrm{C} 2$ and $\mathrm{C} 3$ did not differ significantly $(P>0.05)$. Furthermore, it presents the trend that $\mathrm{C} 1>\mathrm{C} 2>\mathrm{C} 3$, in the reverse sequence of dosages. Based on the results above, at the present dose tested, the diet dosage of $0.04 \mathrm{~g} \cdot \mathrm{d}^{-1}$ was more suitable for CC of femur in OVX rats.

\subsection{Effect of BCAP on BMD of rats}

The results of BMD determination are shown in Figure 2. BMD of proximal end, middle segment, and distal end in group B was all lower than those of group A significantly, which indicated bone loss due to the estrogen declining in OVX rats. This observation is consistent with the results 


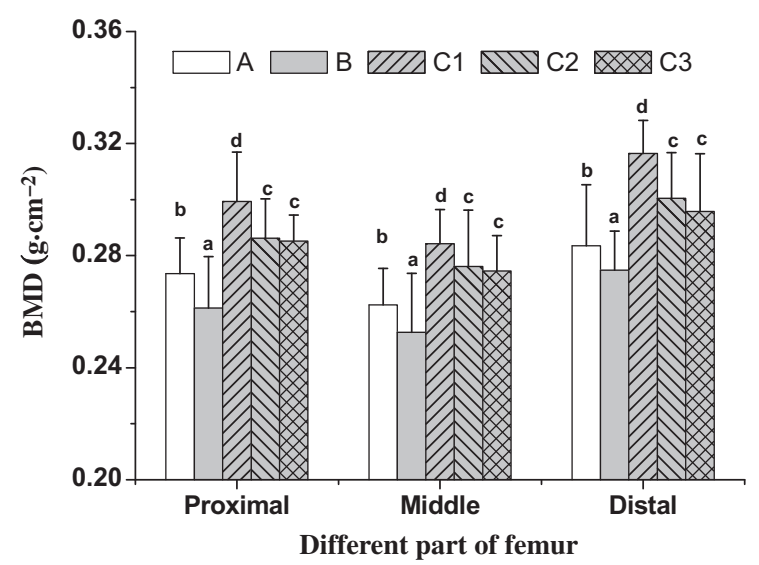

Figure 2. Effect on BMD (mean $\pm \mathrm{SD}, n=10$ ). BMD was measured using dual-energy X-ray absorptiometry. Proximal, proximal end; middle, middle segment; distal, distal end. A, sham operation; B, OVX model control; C1, OVX rats diet with BCAP of $0.04 \mathrm{~g} \cdot \mathrm{d}^{-1}$; C2, OVX rats diet with BCAP of $0.20 \mathrm{~g} \cdot \mathrm{d}^{-1} ; \mathrm{C} 3$, OVX rats diet with BCAP of $0.40 \mathrm{~g} \cdot \mathrm{d}^{-1}$. Values followed by different single letters are significantly different $(P<0.05)$.

of the CC assay above and further confirms that the establishment of animal model was successful.

BMD of groups $\mathrm{C} 1, \mathrm{C} 2$, and $\mathrm{C} 3$ was higher than that of groups $\mathrm{A}$ and $\mathrm{B}$ significantly. $\mathrm{C} 1$ was the highest among the five groups and markedly higher than $\mathrm{C} 2$ and $\mathrm{C} 3$. However, the effects of $\mathrm{C} 2$ and $\mathrm{C} 3$ were similar, which may be caused by the dual effects of BCAP on both osteoblasts and osteoclasts. Moreover, the three doses of BCAP exhibited stronger activity on BMD of distal end of bone, which was also reported by an other research [26]. Therefore, it seemed that BCAP inhibited the bone loss due to the estrogen declining in OVX rats and had positive effects on BMD. Diet with a lower dosage exhibited a stronger activity.

\subsection{Composition of BCAP}

After loading the BCAP sample onto a Sephadex G-100 column, the elution profile showed three major fractions. Based on the purity requirement, one of the three fractions was collected and subjected to Econo-pac Q column, with a typical elution profile revealing three major fractions. Under the conditions used in this study, five isolated fractions existed after the above procedures. The proteins in four among five fractions were purified to homogeneity based on the BCAP preparation and subsequent separation by size exclusion chromatography and anion exchange chromatography. According to the N-terminal amino acid sequence analysis results, lactoferrin (LF), osteopontin (OPN), IGF-2, and epidermal growth factor (EGF) were identified to the dominant proteins in BCAP. Moreover, the other fraction was a mixture dominated by peptides with low molecular weight $\left(<10 \mathrm{~kg} \cdot \mathrm{mol}^{-1}\right)$ [9].

\section{DISCUSSION}

When a rat is ovariectomized, some subsequent symptoms emerge, including declining estrogen levels, increasing body weight, uterus atrophy, and osteoporosis, 
which are typical characteristics of menopausal females [6, 35]. The model of OVX female rats has been widely adopted as a representative model of osteoporosis for menopausal females or as a model of bone loss associated with the menopause $[4,33,44,46]$.

Based on the results of $W / L$, there could be many effective factors to indicate the density of femur directly, such as weight, length, marrow content, marrow density, and the average area of cross-section of femur. With precise measurement of bone volume unavailable, $W / L$ could not be the valid evidence of BMD. $W / L$ was merely an indirect clue of the effects on bone growth as suggested by previous research [26].

This study revealed that BCAP with $0.04 \mathrm{~g} \cdot \mathrm{d}^{-1}$ significantly increased $\mathrm{CC}$ and BMD of the proximal end, the middle segment, and the distal end of femur in OVX rats. This positive effect was true for the distal end. It is known that the distal end of femur consists of cancellous bone enriched in trabecular bone and the diaphysis of bone mainly consists of cortical bone. The density of cortical bone changes slower than that of cancellous bone with the development of femur and could not be observed during a short period [24, 31, 38, 42]. Therefore, during the 12-week experimental period in this study, the changes in BMD of the distal end of femur in the groups of rats treated with different doses of BCAP were more significant compared with the changes in the proximal end and middle segment.

In the study by Yao et al. [47], the proliferation of neonatal rat calvaria osteoblastic cells in the medium which were treated with $\mathrm{BCE}$ took place. The growth rates were all stimulated in dose dependence at the range of $0.002-20 \mathrm{mg} \cdot \mathrm{mL}^{-1}$, but the activity of BCE would be inhibited if the dose exceeded continuously [47]. There are many kinds of growth factors in $\mathrm{BC}$, such as EGF, IGF-1, and IGF-2. These growth factors are capable of promoting the miosis of osteoblasts from juvenile cells, inducing the synthesis of collagen and matrix protein by osteoblasts, and consequently promoting the formation of bone matrix, calcifying the bone, and increasing BMD. Francis [12] and Francis et al. [13] reported that there are many acid stable proteins with low molecular weight in colostrums, such as IGF-1 and IGF-2 and other growth factors. These proteins have positive effects on protein synthesis of L6 myoblasts responsible for the proliferation and differentiation of rat osteoblasts.

The effect of basic proteins from whey of bovine milk on BMD of OVX rats had been investigated by $\mathrm{Lu}$ et al. [26] MBP was reported to exhibit positive activities on BMD of OVX rats at an optimum dosage of $0.01 \mathrm{~g} \cdot(\mathrm{kg} \cdot \mathrm{bw})^{-1}$. In this study, BCAP with all dosages had positive effects on BMD of OVX rats. BMD of group $\mathrm{C} 2$ (BCAP-0.20 g. $\mathrm{d}^{-1}$ ) and group C3 (BCAP$0.40 \mathrm{~g} \cdot \mathrm{d}^{-1}$ ) did not differ significantly and was lower than that of group C1 (BCAP$\left.0.04 \mathrm{~g} \cdot \mathrm{d}^{-1}\right)$, which indicated that BCAP $\left(0.04-0.40 \mathrm{~g} \cdot \mathrm{d}^{-1}\right)$ exhibited activity on BMD not in dose-dependent manner. The dose-dependent manner may exist only in dosages $<0.04 \mathrm{~g} \cdot \mathrm{d}^{-1}$. The low dosages tested had better effect on BMD than medium and high dosages. This finding is consistent with the previous reports and is believed to be caused mainly by a result of two kinds of factors. First, growth factors exert a passive feedback effect when the dosage is excessively high. Second, the growth factors in BC regularly exist in pairs, as some growth factors have stimulatory effects on osteoblasts and other growth factors on osteoclasts. The twin growth factors induce opposing activities and limit each other's activity, and there is a dynamic balance between their effects in the course of metabolism [10, 15, 18, 25, 28, 29, 32]. Based on the relationship of the dosages tested and their effects on bone growth, there exists great potential to optimize the dosage level in future experiments. 
Four kinds of dominant proteins in BCAP, LF, OPN, EGF, and IGF-2 were identified by us. LF has an alkaline $\mathrm{pI}$ value (8.0-8.6) and appears in BCAP, which can probably account for protein-protein interactions. It has been demonstrated that LF can electrostatically associate with OPN and bind to OPN immobilized on a column $[3,11]$. In addition, a group of peptides with low molecular weight $\left(<10 \mathrm{~kg} \cdot \mathrm{mol}^{-1}\right)$ were found in BCAP; the authors presumed that these peptides are growth factors, such as IGF-1 or other functional peptides, immigrating with other proteins in BCAP in anion exchange chromatography. Many studies on the direct or indirect effects of these functional proteins on osteoporosis have been reported $[5,8,11,26,29,36$, 37]. They are closely associated with development and maintenance of bone, stimulation of the growth of osteoblasts and inhibition of osteoclasts, and prevention and treatment of osteoporosis.

The nutrition and safety of functional additives of food have attracted more attention, and BC and BCAP did not make an exception. The nutritional and physiological safety of BC was evaluated by Davis et al. [7]. Results showed that rats exhibited no biochemical, physical, or histopathological abnormalities after being fed for 90 days with a chow supplemented with up to $10 \%$ colostrums.

It is well known that blood biochemistry parameter is a valid reflection of the permeability of organic cells and the metabolism function of organ. Results in this study have shown that all dosages of BCAP (0.04$0.40 \mathrm{~g} \cdot \mathrm{d}^{-1}$ ) have no obvious effects on the blood biochemistry parameters, and there was no significant difference among the parameters of groups $\mathrm{C} 1, \mathrm{C} 2$, and $\mathrm{C} 3$. The results indicate that BCAP have no potential hazard on blood lipids under present experimental condition. Further studies in human beings are required to confirm the long-term safety of colostrums consumption.
Acknowledgments: This study was supported by Natural Scientific Research Innovation Foundation in Harbin Institute of Technology (HIT. NSRIF. 2008. 20). Moreover, we thank Dr. S. Wang in College of Public Health, Harbin Medical University, for his technical assistance on animal experiments, and we also thank Dr. S. Zeng in School of Agriculture and Applied Sciences, Langston University, for his help in our manuscript writing.

\section{REFERENCES}

[1] American Institute of Nutrition, Report of the American Institute of Nutrition ad hoc committee on standards for nutritional studies, J. Nutr. 107 (1977) 1340-1348.

[2] American Institute of Nutrition, Second report of the ad hoc committee on standards for nutritional studies, J. Nutr. 110 (1980) 1726.

[3] Azuma N., Maeta A., Fukuchi K., Kanno C., A rapid method for purifying osteopontin from bovine milk and interaction between osteopontin and other milk proteins, Int. Dairy J. 16 (2006) 370-378.

[4] Compston Juliet E., Sex steroid and bone, Physiol. Rev. 81 (2001) 419-444.

[5] Cornish J., Callon K.E., Naot D., Palmano K.P., Banovic T., Bava U., Watson M., Lin J.M., Tong P.C., Chen Q., Chan V.A., Reid H.E., Fazzalari N., Baker H.M., Baker E.N., Haggarty N.W., Grey A.B., Reid I.R., Lactoferrin is a potent regulator of bone cell activity and increases bone formation in vivo, Endocrinology 145 (2004) 43664374.

[6] Cui L., Wu T., Liu X., Liu Y., Low dose estrogen combined with traditional Chinese medicine prevents osteoporosis in ovariectomized rats, Chin. J. Osteoporos. 9 (2003) 200-204 [in Chinese].

[7] Davis P.F., Greenhill N.S., Rowan A.M., Schollum L.M., The safety of New Zealand bovine colostrums: nutritional and physiological evaluation in rats, Food Chem. Toxicol. 45 (2007) 229-236.

[8] Denhardt D.T., Noda M., O’Regan A.W., Pavlin D., Berman J.S., Osteopontin as a means to cope with environmental insults: regulation of inflammation, tissue remodeling, and cell survival, J. Clin. Investig. 107 (2001) 1055-1061. 
[9] Du M., Xu W., Yi H., Han X., Zhang L., Beneficial effects of bovine colostrum acid protein on bone properties of ovariectomized rats, 19th International Congress of Nutrition 2009, Bangkok, Thailand.

[10] Ermond V.B., Clemens L., Marcel K., Socrates P., Independent pathways in the modulation of osteoclastic resorption by intermediates of the mevalonate biosynthetic pathway: the role of the retinoic acid receptor, Bone 38 (2006) 167-171.

[11] Fong B.Y., Norris C.S., Palmano K.P., Fractionation of bovine whey proteins and characterisation by proteomic techniques, Int. Dairy J. 18 (2008) 23-46.

[12] Francis G.I., Purification and partial sequence analysis of insulin like growth factor 1 from bovine colostrums, Biochem. J. 233 (1986) 207-210.

[13] Francis G.L., Upton F.M., Ballard F.J., McNeil K.A., Wallace J.C., Insulin-like growth factors 1 and 2 in bovine colostrum. Sequences and biological activities compared with those of a potent truncated form, Biochem. J. 251 (1988) 95-103.

[14] Ginty F., Rennie K.L., Mills L., Stear S., Jones S., Prentice A., Positive, site-specific associations between bone mineral status, fitness, and time spent at high-impact activities in 16- to 18-year-old boys, Bone 36 (2005) 101-110.

[15] Goff J., Reinhardt T., Lee S., Hollis B., Parathyroid hormone-related peptide content of bovine milk and calf blood assessed by radioimmunoassay and bioassay, Endocrinology 129 (1991) 2815-2819.

[16] Gu W., Kirsten L.R., Lin X., Wang Y.F., Yu Z.J., Differences in bone mineral status between urban and rural Chinese men and women, Bone 41 (2007) 393-399.

[17] Jouan P.N., Pouliot Y., Gauthier S.F., Laforest J.P., Hormones in bovine milk and milk products: a survey, Int. Dairy J. 16 (2006) 1408-1414.

[18] Kazuya O., Akihide N., Morihiro M., Masanori I., Atsunori F., Jun H., Hideki Y., Iichiro S., Adiponectin increases bone mass by suppressing osteoclast and activating osteoblast, Biochem. Biophys. Res. Commun. 331 (2005) 520-526.

[19] Kelly G.S., Bovine colostrums a review of clinical uses, Altern. Med. Rev. 8 (2003) 378-394.
[20] Kruger C.L., Marano K.M., Morita Y., Takada Y., Kawakami H., Kobayashi T., Sunaga M., Furukawa M., Kawamura K., Safety evaluation of a milk basic protein fraction, Food Chem. Toxicol. 45 (2007) 1301-1307.

[21] Kruger M.C., Plimmer G.G., Schollum L.M., Haggarty N., Ram S., Palmano K., The effect of whey acidic protein fractions on bone loss in the ovariectomised rat, Br. J. Nutr. 93 (2005) 244-252.

[22] Kruger M.C., Poulsen R.C., Schollum L., Haggarty N., Ram S., Palmano K., A comparison between acidic and basic protein fractions from whey or milk for reduction of bone loss in the ovariectomised rat, Int. Dairy J. 16 (2006) 1149-1156.

[23] Lee J., Kwon S.H., Kim H.M., Fahey S.N., Knighton D.R., Sansom A., Effect of growth protein-colostrum fraction on bone development in juvenile rats, Biosci. Biotechnol. Biochem. 72 (2008) 1-6.

[24] Li X.J., Jee W.S., Age-related changes of cancerous and cortical bone histomorphometry in female Sprague-Dawley rats, Cells Mater. 1 (1991) 25-35.

[25] Li Z., Kong K., Qi W., Osteoclast and its roles in calcium metabolism and bone development and remodeling, Biochem. Biophys. Res. Commun. 343 (2006) 345350.

[26] Lu Y., Chai W., Lin X., Effect of milk basic protein on rat bone mineral density, J. Hyg. Res. 36 (2007) 37-40 [in Chinese].

[27] Morita Y., Matsuyama H., Serizawa A., Takeya T., Kawakami H., Identification of angiogenin as the osteoclastic bone resorption-inhibitory factor in bovine milk, Bone 42 (2008) 380-387.

[28] Nakamura A., Ly C., Cipetić M., Natalie A.S., Vieusseux J., Kartsogiannis V., Bouralexis S., Saleh H., Zhou H., Price J.T., Martin T.J., Kong W.N., Matthew T.G., Julian M.W.Q., Osteoclast inhibitory lectin (OCIL) inhibits osteoblast differentiation and function in vitro, Bone 40 (2007) 305-315.

[29] Okuda N., Takeda S., Shinomiya K., Muneta T., Itoh S., Noda M., Asou Y., ED-71, a novel vitamin $\mathrm{D}$ analog, promotes bone formation and angiogenesis and inhibits bone resorption after bone marrow ablation, Bone 40 (2007) 281-292.

[30] Pouliot Y., Gauthier S.F., Milk growth factors as health products: some technological aspects, Int. Dairy J. 16 (2006) 1415-1420. 
[31] Ruegsegger P., Durand E.P., Dambacher M.A., Different effects of aging and disease on trabecular and compact bone density of the radius, Bone 12 (1991) 99-105.

[32] Schmidmaier G., Wildemann B., Heeger J., Gäbelein T., Flyvbjerg A., Bail H.J., Raschke M., Improvement of fracture healing by systemic administration of growth hormone and local application of insulin-like growth factor-1 and transforming growth factor- $\beta 1$, Bone 31 (2002) 165-172.

[33] Seeman E., Invited review: pathogenesis of osteoporosis, J. Appl. Physiol. 95 (2003) 2142-2151.

[34] Siddiqui N.A., Shetty K.R., Duthie E.H.J.R., Osteoporesis in older men: discovering when and how to treat it, Geriatrics 54 (1999) 20-22, 27-28, 30.

[35] Sims N.A., Morris H.A., Moore R.J., Durbridge T.C., Estradiol treatment transiently increases trabecular bone volume in ovariectomized rats, Bone 19 (1996) 455461.

[36] Smithers G.W., Whey and whey proteins: from 'gutter-to-gold', Int. Dairy J. 18 (2008) 695-704.

[37] Tabensky A.D., Williams J., Deluca V., Briganti E., Seeman E., Bone mass, areal, and volumetric bone density are equally accurate, sensitive, and specific surrogates of the breaking strength of the vertebral body: an in vitro study, J. Bone Miner. Res. 11 (1996) 1981-1988.

[38] Takagi T., Yamamoto T., Asano S., Tamaki H., Effect of prostaglandin D2 on the femoral bone mineral density in ovariectomized rats, Calcif. Tissue Int. 52 (1993) 442-446.

[39] Toba Y., Takada Y., Matsuoka Y., Morita Y., Motouri M., Hirai T., Suguri T., Aoe S., Kawakami H., Kumegawa M., Takeuchi A., Itabashi A., Milk basic protein promotes bone formation and suppresses bone resorption in healthy adult men, Biosci. Biotechnol. Biochem. 65 (2001) 1353-1357.

[40] Toba Y., Takada Y., Yamamura J., Tanaka M., Matsuoka Y., Kawakami H., Itabashi A., Aoe S., Kumegawa M., Milk basic protein: a novel protective function of milk against osteoporosis, Bone 27 (2000) 403-408.

[41] Uruakpa F.O., Ismond M.A.H., Akobundu E.N.T., Colostrum and its benefits: a review, Nutr. Res. 22 (2002) 755-767.

[42] Vanderschueren D., Van Herck E., Suiker A.M., Visser W.J., Schot L.P., Bouillon R., Bone and mineral metabolism in aged male rats short and long term effects of androgen deficiency, Endocrinology 130 (1992) 29062916.

[43] Vidal K., Broek P.V.D., Lorget F., DonnetHughes A., Osteoprotegerin in human milk: a potential role in the regulation of bone metabolism and immune development, Pediatr. Res. 55 (2004) 1001-1008.

[44] Xie Z., Li Q., Meng P., Tan Z., Characteristics of osteoporosis models in ovariectomized rats, Chin. J. Clin. Rehabil. 10 (2006) 79-81.

[45] Yamamura J.I., Takada Y., Goto M., Kumegawa M., Aoe S., High mobility group-like protein in bovine milk stimulates the proliferation of osteoblastic MC3T3-E1 cells, Biochem. Biophys. Res. Commun. 261 (1999) 113-117.

[46] Yao W., Hadi T., Basic fibroblast growth factor improves trabecular bone connectivity and bone strength in the lumbar vertebral body of osteopenic rats, Osteoporos. Int. 16 (2005) 1939-1947.

[47] Yao W., Tang Z., Wang D., Jin W., Meng Q., Cao P., Influences of bovine colostrums extract (BCE) on proliferation of osteoblasts and bone development of fetal rats, J. Nanjing Agric. Univ. 22 (1999) 59-63 [in Chinese]. 